\title{
Responses of nitrous oxide emissions to nitrogen and phosphorus additions in two tropical plantations with $\mathrm{N}$-fixing vs. non-N-fixing tree species
}

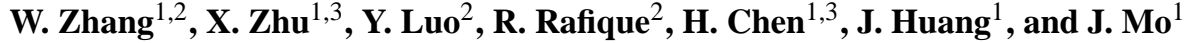 \\ ${ }^{1}$ Key Laboratory of Vegetation Restoration and Management of Degraded Ecosystems, South China Botanical Garden, \\ Chinese Academy of Sciences, Guangzhou 510650, China \\ ${ }^{2}$ Department of Microbiology and Plant Biology, University of Oklahoma, Norman, OK, 73019, USA \\ ${ }^{3}$ University of Chinese Academy of Sciences, Beijing 100039, China
}

Correspondence to: J. Mo (mojm@scib.ac.cn)

Received: 15 October 2013 - Published in Biogeosciences Discuss.: 22 January 2014

Revised: 28 May 2014 - Accepted: 31 July 2014 - Published: 16 September 2014

\begin{abstract}
Leguminous tree plantations at phosphorus (P) limited sites may result in excess nitrogen $(\mathrm{N})$ and higher rates of nitrous oxide $\left(\mathrm{N}_{2} \mathrm{O}\right)$ emissions. However, the effects of $\mathrm{N}$ and $\mathrm{P}$ applications on soil $\mathrm{N}_{2} \mathrm{O}$ emissions from plantations with $\mathrm{N}$-fixing vs. non-N-fixing tree species have rarely been studied in the field. We conducted an experimental manipulation of $\mathrm{N}$ and/or $\mathrm{P}$ additions in two plantations with Acacia auriculiformis (AA, N-fixing) and Eucalyptus urophylla (EU, non-N-fixing) in South China. The objective was to determine the effects of $\mathrm{N}$ or $\mathrm{P}$ addition alone, as well as NP application together on soil $\mathrm{N}_{2} \mathrm{O}$ emissions from these tropical plantations. We found that the average $\mathrm{N}_{2} \mathrm{O}$ emission from control was greater in the $A A(2.3 \pm 0.1 \mathrm{~kg}$ $\left.\mathrm{N}_{2} \mathrm{O}-\mathrm{N} \mathrm{ha}^{-1} \mathrm{yr}^{-1}\right)$ than in $E U$ plantation $\left(1.9 \pm 0.1 \mathrm{~kg} \mathrm{~N}_{2} \mathrm{O}-\right.$ $\left.\mathrm{Nha}^{-1} \mathrm{yr}^{-1}\right)$. For the $A A$ plantation, $\mathrm{N}$ addition stimulated $\mathrm{N}_{2} \mathrm{O}$ emission from the soil while $\mathrm{P}$ addition did not. Applications of $\mathrm{N}$ with $\mathrm{P}$ together significantly decreased $\mathrm{N}_{2} \mathrm{O}$ emission compared to $\mathrm{N}$ addition alone, especially in the high-level treatments (decreased by $18 \%$ ). In the $E U$ plantation, $\mathrm{N}_{2} \mathrm{O}$ emissions significantly decreased in $\mathrm{P}$-addition plots compared with the controls; however, $\mathrm{N}$ and NP additions did not. The different response of $\mathrm{N}_{2} \mathrm{O}$ emission to $\mathrm{N}$ or $\mathrm{P}$ addition was attributed to the higher initial soil $\mathrm{N}$ status in the $A A$ than that of $E U$ plantation, due to symbiotic $\mathrm{N}$ fixation in the former. Our result suggests that atmospheric $\mathrm{N}$ deposition potentially stimulates $\mathrm{N}_{2} \mathrm{O}$ emissions from leguminous tree plantations in the tropics, whereas $\mathrm{P}$ fertiliza-
\end{abstract}

tion has the potential to mitigate $\mathrm{N}$-deposition-induced $\mathrm{N}_{2} \mathrm{O}$ emissions from such plantations.

\section{Introduction}

Nitrous oxide is a powerful greenhouse gas that is 298 times more potent than carbon dioxide $\left(\mathrm{CO}_{2}\right)$ over a $100 \mathrm{yr}$ lifespan (IPCC, 2007), and contributes to stratospheric ozone $\left(\mathrm{O}_{3}\right)$ depletion (Ravishankara et al., 2009). Atmospheric $\mathrm{N}_{2} \mathrm{O}$ concentration has been increasing by $0.2-0.3 \% \mathrm{yr}^{-1}$ over the last $250 \mathrm{yr}$ (Stocker et al., 2013). $\mathrm{N}_{2} \mathrm{O}$ is naturally produced by bacterial metabolism during nitrification and denitrification processes in many environments, particularly soils (Barnard et al., 2005). Tropical forest soils are an important source for $\mathrm{N}_{2} \mathrm{O}$ emission, accounting for $14 \%$ to $23 \%$ of current global $\mathrm{N}_{2} \mathrm{O}$ budget (IPCC, 2007). The major factors of controlling $\mathrm{N}_{2} \mathrm{O}$ emission are soil $\mathrm{N}$ availability, dissolved organic $\mathrm{C}$ (DOC), soil temperature, moisture, and $\mathrm{pH}$ value (Rowlings et al., 2012).

Anthropogenic activities have great impact on the global and regional $\mathrm{N}$ cycles, thereby enhancing the mobility of reactive $\mathrm{N}$ within ecosystems (Vitousek et al., 1997). Atmospheric $\mathrm{N}$ deposition has increased dramatically during recent decades due to intensive agricultural production, fossil fuel combustion, and cultivation of N-fixing plants (Galloway et al., 2008). Worldwide $\mathrm{N}$ deposition is projected to increase by $50 \%$ to $100 \%$ in 2030 relative to 2000 , with 
the greatest increases occurring in tropical regions such as Southeast Asia and Latin America (Reay et al., 2008). In China, the rate of $\mathrm{N}$ deposition has increased since the $1980 \mathrm{~s}$ and is projected to increase in the coming decades (Liu et al., 2013). $\mathrm{N}_{2} \mathrm{O}$ emissions have often been found to be elevated from the forest soils exposed to high $\mathrm{N}$ inputs including $\mathrm{N}$ deposition, fertilization, or biological $\mathrm{N}$ fixation via leguminous trees (Venterea et al., 2003; Zhang et al., 2008; Arai et al., 2008).

In contrast to temperate forests, primary production in many tropical forests is limited by $\mathrm{P}$ rather than by $\mathrm{N}$ availability (Vitousek et al., 2010). Previous studies found that P-limited forests could emit more $\mathrm{N}_{2} \mathrm{O}$ than the N-limited forests after $\mathrm{N}$ fertilization. Hall and Matson (1999) measured $\mathrm{N}_{2} \mathrm{O}$ emission after adding $\mathrm{N}$ in two tropical rainforests in Hawaii (USA), and found that $\mathrm{N}_{2} \mathrm{O}$ emission from a Plimited site was 54 times greater compared with that from a N-limited site. Martinson et al. (2013) also found lower $\mathrm{N}_{2} \mathrm{O}$ emissions when $\mathrm{N}$ and $\mathrm{P}$ were applied together compared to $\mathrm{N}$ application alone in tropical montane forests. This is because the poor $\mathrm{P}$ availability of tropical forests may decrease $\mathrm{N}$ uptake and immobilization and hence cause higher $\mathrm{N}_{2} \mathrm{O}$ emission (Hall and Matson, 1999; Martinson et al., 2013). However, most studies have been carried out in natural forests while very few in tropical plantations (Martinson et al., 2013; Mori et al., 2013).

According to the Food and Agriculture Organization of the United Nations (FAOUN, 2010), plantations occupy about 264 million hectares worldwide. The total area of plantations in China is 62 million ha, accounting for approximately $32 \%$ of the total forest area (available data from the seventh national forest resources inventory survey of China: http://www.forestry.gov.cn/main/65/content-326341. html). The percentage of forest land cover in South China increased from 26\% in 1979 to $56 \%$ in 2005 (Peng et al., 2009). In this region, most planted tree species are Acacia spp., Eucalyptus spp., and some native species (Chen et al., 2011), especially on eroded and degraded lands. Leguminous tree plantations at $\mathrm{P}$-limited sites may result in higher rates of $\mathrm{N}_{2} \mathrm{O}$ emissions, if excess $\mathrm{N}$ easily promotes $\mathrm{N}_{2} \mathrm{O}$ emission from P-limited soils (Arai et al., 2008; Konda et al., 2008). Fertilization of $\mathrm{N}$ and/or $\mathrm{P}$ is a common practice to improve productivity in plantation management in the tropical and subtropical regions. However, direct evidence of $\mathrm{N}$ and $\mathrm{P}$ addition on soil $\mathrm{N}_{2} \mathrm{O}$ emissions in tropical forests is still rare (Hall and Matson, 1999; Koehler et al., 2009), especially from plantations with $\mathrm{N}$-fixing vs. non-N-fixing tree species (Mori et al., 2013).

In this study, the main objective was to determine the different effects of $\mathrm{N}$ or $\mathrm{P}$ addition alone, and their interaction on $\mathrm{N}_{2} \mathrm{O}$ emissions from tropical plantations with $\mathrm{N}$-fixing (Acacia auriculiformis, AA) vs. non-N-fixing tree species (Eucalyptus urophylla, EU) and clarify the underlying mechanisms of $\mathrm{N}_{2} \mathrm{O}$ production. We hypothesized the following: (i) $\mathrm{N}$ addition would enhance $\mathrm{N}_{2} \mathrm{O}$ emissions more in the $A A$ plantation due to its relatively higher initial soil $\mathrm{N}$ availability compared to the $E U$ plantation, because of additional $\mathrm{N}$ input into the former via biological $\mathrm{N}$ fixation by leguminous trees; (ii) $\mathrm{P}$ addition would decrease $\mathrm{N}_{2} \mathrm{O}$ emissions in both plantations due to stimulated uptake and/or immobilization of $\mathrm{N}$ by the alleviation of $\mathrm{P}$ limitation; and (iii) $\mathrm{N}$ and $\mathrm{P}$ interaction would reduce $\mathrm{N}$-addition-induced $\mathrm{N}_{2} \mathrm{O}$ emission from the soils of both plantations.

\section{Materials and methods}

\subsection{Site description}

This study was conducted at the Heshan National Field Research Station of Forest Ecosystems (112 $\left.50^{\prime} \mathrm{E}, 22^{\circ} 34^{\prime} \mathrm{N}\right)$, which is located in the middle of Guangdong Province, South China. The region has a tropical monsoon climate with a distinct wet and dry season. The average annual precipitation and air temperature were $1295 \mathrm{~mm}$ and $21.7^{\circ} \mathrm{C}$, respectively (Chen et al., 2011). $\mathrm{N}$ deposition in rainfall was $43.1 \pm 3.9 \mathrm{~kg} \mathrm{~N} \mathrm{ha}^{-1} \mathrm{yr}^{-1}$, with almost equal contributions from oxidized and reduced forms (unpublished data, measured from July 2010 to June 2012). Plantations with Nfixing and non-N-fixing tree species (located $500 \mathrm{~m}$ apart) were used in this experiment. The dominant species in the canopy layer was Acacia auriculiformis in the $A A$ plantation, and Eucalyptus urophylla in the EU plantation. As a result of long-term disturbances, the soil in this area has eroded, leading to vast areas of degraded lands. The $A A$ and $E U$ plantations are commonly used for promoting forest restoration on the degraded lands in this region. Indices of the tree structure of both plantations are given in Supplement Table S1. The soils in both sites are classified as lateritic soils (Chen et al., 2011), and soil bulk density is 1.2 and $1.1 \mathrm{~g} \mathrm{~cm}^{-3}$ for the $A A$ and $E U$ stand, respectively.

\subsection{Experimental design}

An experimental manipulation of nutrient additions was conducted with a complete randomized block design. Three blocks (three replicates) were established per plantation in July 2010. Each block had seven treatments which were randomly assigned to $10 \mathrm{~m} \times 10 \mathrm{~m}$ plots. Each plot was surrounded by a $10 \mathrm{~m}$ buffer strip to the next plot. The treatments included control $(\mathrm{C}$, without $\mathrm{N}$ and $\mathrm{P}$ addition), medium $\mathrm{N}\left(\mathrm{MN}, 50 \mathrm{~kg} \mathrm{Nha}^{-1} \mathrm{yr}^{-1}\right)$, high $\mathrm{N}(\mathrm{HN}$, $100 \mathrm{~kg} \mathrm{Nha}^{-1} \mathrm{yr}^{-1}$ ), medium $\mathrm{P}$ (MP, $50 \mathrm{~kg} \mathrm{Pha}^{-1} \mathrm{yr}^{-1}$ ), high $\mathrm{P}$ (HP, $\left.100 \mathrm{~kg} \mathrm{Pha}^{-1} \mathrm{yr}^{-1}\right)$, medium NP (MNP, $50 \mathrm{~kg} \mathrm{Nha}^{-1} \mathrm{yr}^{-1}+50 \mathrm{~kg} \mathrm{Pha}^{-1} \mathrm{yr}^{-1}$ ), and high NP (HNP, $\left.100 \mathrm{~kg} \mathrm{Nha}^{-1} \mathrm{yr}^{-1}+100 \mathrm{~kg} \mathrm{Pha}^{-1} \mathrm{yr}^{-1}\right)$. Ammonium nitrate $\left(\mathrm{NH}_{4} \mathrm{NO}_{3}\right)$ and sodium biphosphate $\left(\mathrm{NaH}_{2} \mathrm{PO}_{4}\right)$ were applied as $\mathrm{N}$ and $\mathrm{P}$ source, respectively. The additions were weighed and dissolved in $10 \mathrm{~L}$ water for each plot. The solutions have been sprayed monthly onto the forest floor using 
a backpack sprayer since August 2010. Each control plot received $10 \mathrm{~L}$ water simultaneously with each treatment event.

\subsection{Field sampling and measurements}

\subsection{1 $\quad \mathrm{N}_{2} \mathrm{O}$ flux measurements}

From August 2010 to July 2012, $\mathrm{N}_{2} \mathrm{O}$ fluxes were measured biweekly using a static chamber method. The chamber design and the measurement procedure were adopted from Zhang et al. (2012). Gas samples were collected at 0,15 and 30 min intervals after the chamber closure. $\mathrm{N}_{2} \mathrm{O}$ concentrations were analyzed within $24 \mathrm{~h}$ using a gas chromatograph (Agilent 5890 D, USA) equipped with an electron capture detector (ECD). Fluxes were calculated from the linear rate of change in gas concentration, chamber volume, and soil surface area (Holland et al., 1999), and adjusted for the fieldmeasured air temperature and atmospheric pressure.

\subsubsection{Soil sampling and analyses}

Soil samples were collected in July 2011 and July 2012 for analyzing properties. Three soil cores $(3.5 \mathrm{~cm}$ diameter) were collected randomly from each plot at $0-10 \mathrm{~cm}$ depth and combined to one composite sample. The samples were passed through a $2 \mathrm{~mm}$ sieve and divided into two parts. One part of fresh soil was used for the analysis of ammonium $\left(\mathrm{NH}_{4}^{+}\right)$, nitrate $\left(\mathrm{NO}_{3}^{-}\right)$, microbial biomass $\mathrm{C}(\mathrm{MBC})$, and microbial biomass $\mathrm{N}(\mathrm{MBN})$ contents. The other part was air dried at room temperature $\left(25^{\circ} \mathrm{C}\right)$ for the estimation of other chemical parameters.

Soil $\mathrm{NH}_{4}^{+}$and $\mathrm{NO}_{3}^{-}$contents were determined by extraction with $2 \mathrm{M} \mathrm{KCl}$ solution followed by colorimetric analysis on a flow-injection autoanalyzer (Lachat Instruments, Milwaukee, USA). Total N (TN) content was determined by the micro-Kjeldahl digestion (Bremner and Mulvaney, 1982), followed by detection of $\mathrm{NH}_{4}^{+}$with a UV-8000 Spectrophotometer (Metash Instruments Co., Shanghai, China). Soil organic carbon (SOC) was determined by wet digestion with a mixture of potassium dichromate and concentrated sulfuric acid (Liu et al., 1996). Soil $\mathrm{pH}$ was measured in a $1: 2.5$ soil-water suspension using a pH meter (HM-30G, TOA Co., Japan). Available $\mathrm{P}$ was extracted with $0.03 \mathrm{M}$ ammonium fluoride and $0.025 \mathrm{M}$ hydrochloric acid and analyzed colorimetrically (Anderson and Ingram, 1989). Gravimetric water content was determined through oven drying at $105^{\circ} \mathrm{C}$ for $48 \mathrm{~h}$.

Both soil MBC and MBN were estimated by chloroform fumigation-extraction method (Vance et al., 1987). In brief, fresh soil samples were fumigated with chloroform $\left(\mathrm{CHCl}_{3}\right)$ vapor for $24 \mathrm{~h}$ at $25^{\circ} \mathrm{C}$ then extracted with $0.5 \mathrm{M} \mathrm{K}_{2} \mathrm{SO}_{4}$. Simultaneously, subsamples for non-fumigated soil were also extracted with the same method. Soil MBC and MBN were calculated as the difference in extractable $\mathrm{C}$ and $\mathrm{N}$ between fumigated and non-fumigated soils. The conversion factors of 0.33 and 0.45 were used for calculating soil $\mathrm{MBC}$ and MBN, respectively (Cabrera and Beare, 1993; Tu et al., 2006).

From 1 to 31 July 2012, soil net N mineralization and nitrification were measured using an intact core incubation. Six soil cores $(3.5 \mathrm{~cm}$ diameter) were sampled from each plot. Three cores were brought to the lab for extraction ( $2 \mathrm{M}$ $\mathrm{KCl}$ ) of inorganic $\mathrm{N}$ contents, and the others were returned to the plot for in situ incubation. Nitrification rate was calculated from the difference between extractable $\mathrm{NO}_{3}^{-}$contents before and after incubation, and net $\mathrm{N}$ mineralization rate was calculated as the accumulation of total inorganic $\mathrm{N}$ over the incubation (Zhu and Carreiro, 1999). The data were expressed as $\mathrm{mg} \mathrm{N} \mathrm{kg}^{-1}$ dry weight soil month${ }^{-1}$.

\subsubsection{Litterfall}

Two litterfall traps $(1.0 \mathrm{~m} \times 1.0 \mathrm{~m}$ with a mesh size of $1 \mathrm{~mm})$ were established in each plot. Litter was collected monthly. The samples were oven-dried at $65^{\circ} \mathrm{C}$ for $48 \mathrm{~h}$ and weighed to determine litter mass. Subsamples of dried litter were grounded and analyzed for $\mathrm{N}$ and $\mathrm{P}$ concentrations using $\mathrm{H}_{2} \mathrm{SO}_{4}-\mathrm{H}_{2} \mathrm{O}_{2}$ digestion followed by colorimetric analysis (Dong et al., 1996).

\subsubsection{Soil temperature and moisture}

Air temperature (inside chamber), soil temperature $(5 \mathrm{~cm}$ depth), moisture $(0-10 \mathrm{~cm}$ depth), and atmospheric pressure were measured simultaneously with each gas sampling event. Temperature was measured using a digital thermometer (TES-1310, Ltd., China). Atmospheric pressure was measured at sampling site using an air pressure gauge (Model THOMMEN 2000, Switzerland). Soil moisture $(0-10 \mathrm{~cm}$ depth) was detected using an ADR-probe (Amplitude Domain Reflectometry, Model Top TZS-I, China), and converted to WFPS as the following formula:

$\mathrm{WFPS}=\mathrm{Vol} /(1-\mathrm{SBD} / 2.65)$,

where WFPS is water-filled pore space (\%), Vol is volumetric water content (\%), SBD is soil bulk density $\left(\mathrm{g} \mathrm{cm}^{-3}\right)$, and 2.65 is the soil particle density $\left(\mathrm{g} \mathrm{cm}^{-3}\right)$.

\subsection{Statistics}

Repeated measures analysis of variance (ANOVA) was used to examine the effect of nutrient additions on $\mathrm{N}_{2} \mathrm{O}$ fluxes, soil temperature and WFPS, as well as soil properties from August 2010 to July 2012. Two-way ANOVA was performed to analyze the difference in mean $\mathrm{N}_{2} \mathrm{O}$ emissions, soil properties, MBC, MBN, and litter mass among treatments of each plantation. Multiple regression analysis was performed to evaluate the relationships of $\mathrm{N}_{2} \mathrm{O}$ emissions with soil temperature, WFPS and soil parameters. All statistical analyses were conducted using SPSS 16.0 for windows (SPSS Inc., 
Chicago, IL, USA). Statistically significant difference was set at $p \leq 0.05$. Mean values \pm 1 standard error were reported in the text.

\section{Results}

\subsection{Soil nutrients and $\mathrm{pH}$}

The variations of soil properties were depended on nutrient addition levels and plantation types. Soil available $\mathrm{N}\left(\mathrm{NO}_{3}^{-}\right.$ and $\mathrm{NH}_{4}^{+}$), TN, and SOC contents of the control plots were greater in the $A A$ plantation than in $E U$ stand (Supplement Table S2; $t$ test, $p<0.05$ ). In contrast, soil $\mathrm{pH}$ value of $A A$ was marginally significant lower than that of $E U$ plantation (Supplement Table S3; $p=0.06$ for both years).

During the 2 years, $\mathrm{N}$ addition significantly influenced soil available $\mathrm{N}\left(\mathrm{NH}_{4}^{+}\right.$and $\left.\mathrm{NO}_{3}^{-}\right)$and TN contents of the $A A$ plantation (Table 1 and Supplement S2). For the $E U$ plantation, $\mathrm{N}$ addition significantly increased soil $\mathrm{NO}_{3}^{-}$content, while $\mathrm{NH}_{4}^{+}$and $\mathrm{TN}$ contents had no changes in the first year (Table 1 and Supplement S2). N addition did not change soil $\mathrm{pH}$ of the $E U$ stand; however, a marginally significant decrease in $\mathrm{pH}$ value with $\mathrm{N}$ addition was observed in the $A A$ plantation (Table 2; $p=0.07$ for the two experimental years). After 2 years of $\mathrm{N}$ application, there were no changes in soil available $\mathrm{P}$ of each plantation (Table 1 and Supplement S2). However, there were significant increases of soil available $\mathrm{P}$ contents following $\mathrm{P}$ addition in both plantations (Table 1). In the second experimental year, soil $\mathrm{NO}_{3}^{-}$content decreased significantly following $\mathrm{P}$ addition in the $E U$ plantation ( $p=0.05$ ), but not significantly in the $A A$ stand (Table 1 and Supplement S2; $p=0.4$ ). Soil $\mathrm{pH}$ values of HP were significantly higher than that of $\mathrm{HN}$ treatments in the $A A$ plantation, while the $E U$ site did not (Supplement Table S3; $p<0.05)$. Multiple regression analysis indicated that there were no significant relationships between $\mathrm{N}_{2} \mathrm{O}$ emissions and TN or SOC contents of both plantations.

Applications of NP together significantly increased soil available $\mathrm{P}$ in both plantations (Table 1 and Supplement S2). For the $A A$ plantation, soil available $\mathrm{N}$ slightly increased following NP addition (Table 1 and Supplement S2). The interactions of $\mathrm{N} \times \mathrm{P}$ addition on soil available $\mathrm{N}\left(\mathrm{NO}_{3}^{-}\right.$and $\mathrm{NH}_{4}^{+}$) were found in the $A A$ plantation (Table 1). There was an interactive effect of $\mathrm{N} \times \mathrm{P}$ addition $\times$ year on soil $\mathrm{NO}_{3}^{-}$in the $A A$ plantation (Table 1). For the $E U$ plantation, the interaction of $\mathrm{N} \times \mathrm{P}$ addition on soil $\mathrm{NO}_{3}^{-}$contents was also found (Table 1).

\subsection{Nitrification and net $\mathbf{N}$ mineralization}

In the $A A$ plantation, $\mathrm{N}$ addition significantly increased the rates of nitrification (Fig. 1a; $p=0.03$ ), which were from $11 \pm 3$ in the controls to $23 \pm 3 \mathrm{mg} \mathrm{Ng} \mathrm{soil}{ }^{-1}$ month $^{-1}$ in $\mathrm{HN}$-treatment plots. The rates of net $\mathrm{N}$ mineralization
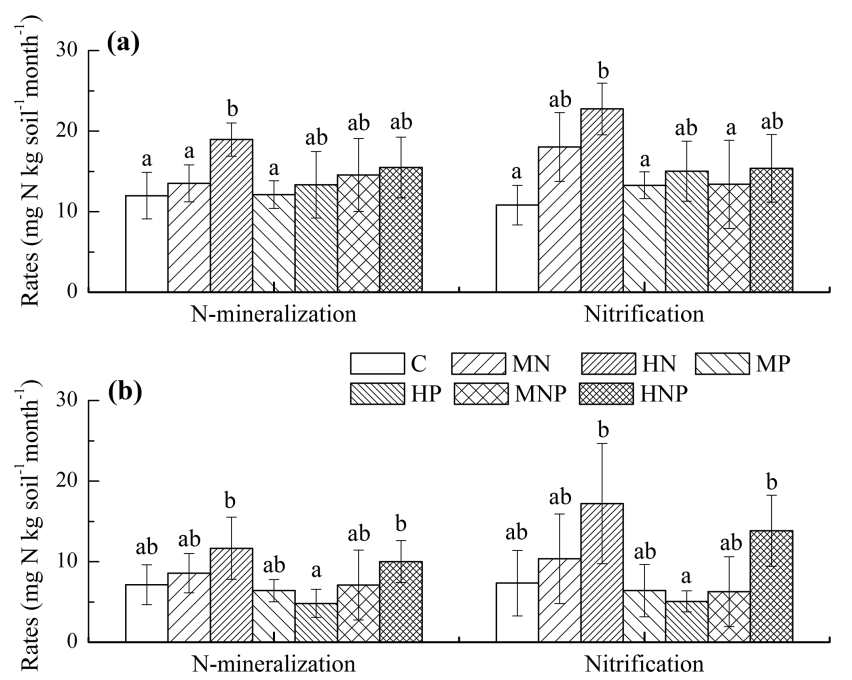

Figure 1. The rates of net $\mathrm{N}$ mineralization and nitrification in the 0-10 cm mineral soil of (a) Acacia auriculiformis and (b) Eucalyptus urophylla plantation. The field incubation was conducted in July 2012 (the second year after nutrient additions). The error bars denote $\pm 1 \mathrm{SE}$. Different letters represent statistically significant differences at $p<0.05$.

also significantly increased following $\mathrm{N}$ treatment levels (Fig. 1a; $p=0.04$ ). The average rates of net $\mathrm{N}$ mineralization were from $12 \pm 3$ in the controls to $14 \pm 2$ and $19 \pm 2 \mathrm{mg} \mathrm{N} \mathrm{kg} \mathrm{soil}^{-1} \mathrm{month}^{-1}$, respectively for the $\mathrm{MN}$ and $\mathrm{HN}$ treatments. However, $\mathrm{P}$ addition or NP addition did not significantly change the rates of nitrification and net $\mathrm{N}$ mineralization (Fig. 1a).

For the $E U$ plantation, $\mathrm{N}$ addition slightly increased the rates of nitrification and net $\mathrm{N}$ mineralization (Fig. 1b). On the contrary, $\mathrm{P}$ addition tended to marginally decrease the rates of nitrification and net $\mathrm{N}$ mineralization (Fig. 1b; $p=0.07$ and 0.06 , respectively for nitrification and net $\mathrm{N}-$ mineralization rate). Accordingly, the rate of nitrification in HP-treatment plots $(5 \pm 1)$ was significantly lower than that in HN (17 \pm 6$)$ and HNP $\left(14 \pm 4 \mathrm{mg} \mathrm{N} \mathrm{kg} \mathrm{soil}{ }^{-1}\right.$ month $\left.^{-1}\right)$ treatment plots (Fig. 1b; $p<0.05$ ). Similarly, the significant differences of net $\mathrm{N}$-mineralization rate between the HP and HN or HNP treatments were found in the field incubation experiment (Fig. 1b; $p<0.05$ ).

\subsection{Soil microbial biomass and litterfall mass}

In the $A A$ plantation, soil MBC tended to decrease with $\mathrm{N}$ application, but there was no significant difference between $\mathrm{N}$-addition plots and the controls (Supplement Table S3). Meanwhile, a marginal increase in soil MBN following $\mathrm{N}$ treatment levels was found in the first year (Supplement Table $\mathrm{S} 3 ; p=0.07)$. NP addition increased soil MBC only in the first year, but did not change MBN (Supplement Table S3). $P$ addition changed neither soil MBC nor MBN throughout the 2 years (Supplement Table S3). For the $E U$ plantation, 
Table 1. Results of repeated measures ANOVA for responses of $\mathrm{N}_{2} \mathrm{O}$ fluxes, soil properties, soil MBC and MBN to $\mathrm{N}$ addition, $\mathrm{P}$ addition and year.

\begin{tabular}{|c|c|c|c|c|c|c|c|c|c|c|c|}
\hline & & $\mathrm{N}_{2} \mathrm{O}$ & $\mathrm{NO}_{3}^{-}$ & $\mathrm{NH}_{4}^{+}$ & $\mathrm{TN}$ & SOC & $\mathrm{C}: \mathrm{N}$ & Av. $\mathrm{P}$ & $\mathrm{MBC}$ & MBN & $\mathrm{pH}$ \\
\hline \multirow{7}{*}{$A A$} & $\mathrm{~N}$ & $<0.01$ & $<0.001$ & $<0.001$ & 0.45 & 0.80 & 0.07 & 0.19 & 0.52 & 0.67 & 0.27 \\
\hline & $\mathrm{P}$ & 0.75 & 0.16 & 0.98 & 0.02 & 0.35 & 0.03 & $<0.001$ & 0.01 & 0.93 & 0.02 \\
\hline & $\mathrm{Y}$ & 0.843 & $<0.001$ & $<0.001$ & $<0.001$ & $<0.001$ & 0.02 & 0.17 & 0.01 & 0.02 & 0.63 \\
\hline & $\mathrm{N} \times \mathrm{P}$ & 0.05 & 0.04 & 0.01 & 0.10 & 0.47 & 0.08 & 0.08 & 0.66 & 0.56 & 0.80 \\
\hline & $\mathrm{N} \times \mathrm{Y}$ & 0.06 & 0.41 & 0.52 & 0.79 & 0.86 & 0.73 & 0.34 & 0.11 & 0.57 & 0.17 \\
\hline & $\mathrm{P} \times \mathrm{Y}$ & 0.06 & 0.79 & 0.46 & 0.99 & 0.39 & 0.56 & 0.001 & 0.12 & 0.93 & 0.07 \\
\hline & $\mathrm{N} \times \mathrm{P} \times \mathrm{Y}$ & 0.17 & 0.02 & 0.95 & 0.48 & 0.79 & 0.63 & 0.33 & 0.16 & 0.47 & 0.94 \\
\hline \multirow{7}{*}{$E U$} & $\mathrm{~N}$ & 0.08 & $<0.001$ & 0.04 & 0.11 & 0.53 & 0.93 & 0.38 & 0.06 & 0.83 & 0.86 \\
\hline & $\mathrm{P}$ & 0.86 & $<0.01$ & 0.03 & 0.22 & 0.07 & 0.64 & $<0.001$ & 0.09 & 0.62 & 0.77 \\
\hline & $\mathrm{Y}$ & 0.11 & $<0.001$ & $<0.001$ & 0.45 & $<0.001$ & $<0.01$ & 0.68 & 0.10 & $<0.01$ & 0.49 \\
\hline & $\mathrm{N} \times \mathrm{P}$ & 0.35 & 0.001 & 0.54 & 0.08 & 0.52 & 0.49 & 0.60 & 0.23 & 0.47 & 0.52 \\
\hline & $\mathrm{N} \times \mathrm{Y}$ & 0.82 & 0.30 & 0.45 & 0.66 & 0.66 & 0.89 & 0.73 & 0.96 & 0.68 & 0.03 \\
\hline & $\mathrm{P} \times \mathrm{Y}$ & 0.04 & 0.04 & 0.10 & 0.92 & 0.47 & 0.86 & $<0.01$ & 0.98 & 0.82 & 0.21 \\
\hline & $\mathrm{N} \times \mathrm{P} \times \mathrm{Y}$ & 0.57 & 0.33 & 0.51 & 0.33 & 0.86 & 0.55 & 0.58 & 0.75 & 0.54 & 0.06 \\
\hline
\end{tabular}

The data were from high $\mathrm{N}$ and $\mathrm{P}$ treatment (HN, HP, HNP additions) plots. $p$ values smaller than 0.05 and 0.10 are in bold and italic, respectively. N, N addition; P, P addition; Y, year, the first year (from August 2010 to July 2011) and the second year (from August 2011 to July 2012 ) after nutrient additions. AA, Acacia auriculiformis plantation; EU, Eucalyptus urophylla plantation. TN, total nitrogen; SOC, soil organic carbon; $\mathrm{C}: \mathrm{N}, \mathrm{SOC}$ : TN ratio; Av. P, soil available P; MBC, soil microbial biomass C; MBN, soil microbial biomass N.

Table 2. Regression analysis between $\mathrm{N}_{2} \mathrm{O}$ fluxes and soil temperature and WFPS in the controls of $A A$ and $E U$ plantations.

\begin{tabular}{|c|c|c|c|}
\hline & $A A(n=108)$ & $E U(n=108)$ & $A A+E U(n=216)$ \\
\hline \multicolumn{4}{|c|}{ Soil temperature $\left(T\right.$ in $\left.{ }^{\circ} \mathrm{C}\right)$} \\
\hline$R^{2}$ & $0.32 * * *$ & $0.35^{* * *}$ & $0.30 * * *$ \\
\hline$p$ & $<0.001$ & $<0.001$ & $<0.001$ \\
\hline$f(T)$ & $1.34 T+2.28$ & $1.43 T+7.44$ & $1.34 T-2.05$ \\
\hline \multicolumn{4}{|c|}{ Soil moisture (M, WFPS, \%) } \\
\hline$R^{2}$ & $0.19 * * *$ & $0.26^{* * *}$ & $0.23 * * *$ \\
\hline$p$ & $<0.001$ & $<0.001$ & $<0.001$ \\
\hline$f(M)$ & $0.49 M+3.70$ & $0.56 M-5.58$ & $0.55 M-2.38$ \\
\hline \multicolumn{4}{|c|}{ Multiple linear regression analysis ( $T$ and $M$ ) } \\
\hline$R^{2}$ & $0.38 * * *$ & $0.43^{* * *}$ & $0.39 * * *$ \\
\hline$p$ & $<0.001$ & $<0.001$ & $<0.001$ \\
\hline$f(T, M)$ & $1.11 T+0.31 M-9.56$ & $1.12 T+0.35 M-18.50$ & $1.06 T+0.38 M-15.05$ \\
\hline
\end{tabular}

there were no changes in soil MBC and MBN following nutrient additions (Supplement Table S3).

There were no differences in annual total litter mass between the controls of both plantations (Supplement Table S3; $t$ test, all $p>0.05)$. The quantity of litter mass among nutrient treatment plots in each plantation was also not significantly different (Supplement Table S3). Multiple regression analysis showed that there was a weak relationship between litter mass and $\mathrm{N}_{2} \mathrm{O}$ emission. Leaf litter $\mathrm{N}$ concentrations were significantly increased by any nutrient additions in the
$E U$ plantation, especially in each high-level treatment (Supplement Table S3). In the $A A$ plantation however, there were no changes in leaf litter $\mathrm{N}$ concentrations following nutrient additions (Supplement Table S3). The fertilization with $\mathrm{P}$ alone, as well as NP together, strongly increased P concentrations of leaf litter, especially in high-level treatments for both plantations (Supplement Table S3; all $p<0.05$ ). N : P ratios of leaf litter significantly decreased by $\mathrm{P}$ addition, as well as NP together (Supplement Table S3; all $p<0.05$ ). The N : P ratio of leaf litter from the controls of $A A$ was significantly 

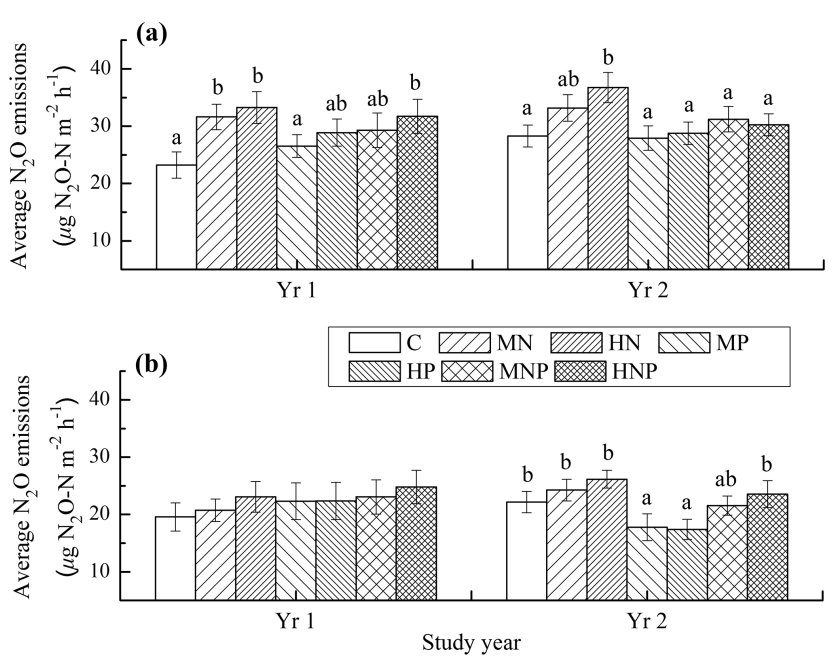

Figure 2. Average $\mathrm{N}_{2} \mathrm{O}$ emission rates for each treatment of (a) Acacia auriculiformis and (b) Eucalyptus urophylla plantations in the first and second year after nutrient additions. The error bars denote \pm 1 SE. Different letters represent significant differences at $p<0.05$. Yr 1: the first year (from August 2010 to July 2011); Yr 2: the second year (from August 2011 to July 2012).

higher than that of $E U$ plantation (Supplement Table S3; $t$ test, $p<0.01$ ).

\subsection{Soil temperature and WFPS}

There were clear seasonal patterns of soil temperature and WFPS in the controls of both plantations, which followed the seasonal patterns of air temperature and rainfall (Supplement Fig. S1). In the control plots, the mean soil temperatures were $20.5 \pm 0.7^{\circ} \mathrm{C}$ and $20.9 \pm 0.6^{\circ} \mathrm{C}$ for $A A$ and $E U$ plantation. The average WFPS was 53 and $49 \%$ for the $A A$ and $E U$ stand, respectively. Monthly means of soil WFPS and temperature were similar between the $A A$ and $E U$ plantations ( $t$ test, $p>0.05$ ). There were no differences between treatments and the controls in each plantation, in terms of soil temperature ( $p=0.7$ and 0.6 , respectively for the $A A$ and $E U$ plantation) and WFPS ( $p=0.9$ for both plantations). In our study, $\mathrm{N}_{2} \mathrm{O}$ fluxes showed positive linear relationships with soil temperatures $\left(R^{2}=0.3\right.$ and 0.4) and WFPS $\left(R^{2}=0.2\right.$ and 0.3 , respectively for $A A$ and $E U$ plantation) (Table 2). Stepwise multiple linear regression analysis indicated that soil temperature and WFPS are the significant variables explaining the variability of $\mathrm{N}_{2} \mathrm{O}$ emissions (Table 2).

\section{$3.5 \quad \mathrm{~N}_{2} \mathrm{O}$ emissions from the controls}

During the 2 years of experimental period, the soils of both plantations were a net source of $\mathrm{N}_{2} \mathrm{O}$ (Fig. 2). Average $\mathrm{N}_{2} \mathrm{O}$ emission from the controls of the $A A$ plantation $\left(2.3 \pm 0.1 \mathrm{~kg} \mathrm{~N}_{2} \mathrm{O}-\mathrm{N} \mathrm{ha}^{-1} \mathrm{yr}^{-1}\right)$ was significantly greater ( $t$ test, $p=0.007$ ) than that of the $E U$ plantation $\left(1.9 \pm 0.1 \mathrm{~kg} \mathrm{~N}_{2} \mathrm{O}-\mathrm{N} \mathrm{ha}^{-1} \mathrm{yr}^{-1}\right)$. The $A A$ plantation showed more and higher $\mathrm{N}_{2} \mathrm{O}$ peaks compared to the $E U$ plantation (Supplement Fig. S2). $\mathrm{N}_{2} \mathrm{O}$ emissions of both plantations tended to be higher in summer (June to August) than in winter (November to January of next year) (Supplement Fig. S2; $p<0.05$ for both plantations).

\subsection{Effects of nutrient additions on $\mathrm{N}_{2} \mathrm{O}$ fluxes}

In the $A A$ plantation, $\mathrm{N}_{2} \mathrm{O}$ emissions significantly increased following $\mathrm{N}$ applications (Fig. 2a; all $p<0.05$ ), however, did not change following $\mathrm{P}$ addition relative to the controls (Fig. 2a; all $p>0.05$ ). During the 2 years of experimental period, the $\mathrm{MN}$ and $\mathrm{HN}$ treatments significantly increased soil $\mathrm{N}_{2} \mathrm{O}$ emissions by $16 \%$ and $36 \%$, respectively (Fig. 2a; $p=0.05$ and 0.04 , respectively for the $\mathrm{MN}$ and $\mathrm{HN}$ treatment). The $\mathrm{NP}$ addition significantly increased $\mathrm{N}_{2} \mathrm{O}$ emission in the first year, especially for HNP treatments (increased by $33 \%$ ) compared with the controls (Fig. 2a; $p=0.04$ ), but did not in the second. The average $\mathrm{N}_{2} \mathrm{O}$ emission rate of HNP plots was significantly decreased by $18 \%$ compared to that of HN treatments in the second year (Fig. 2a; $p=0.04$ ). Repeated measures analysis indicated that there was a significant interaction of $\mathrm{N} \times \mathrm{P}$ addition on $\mathrm{N}_{2} \mathrm{O}$ emissions from $A A$ plantation soil (Table 1).

For the $E U$ plantation, nutrient additions had no significant effects on soil $\mathrm{N}_{2} \mathrm{O}$ emissions in the first year (Fig. 2b; all $p>0.05$ ). However in the second year, soil $\mathrm{N}_{2} \mathrm{O}$ emissions significantly decreased by $23 \%$ and $27 \%$ for MP and HP treatments compared with the controls (Fig. 2b; $p=0.05$ and 0.04 , respectively for the MP and HP treatment). There was a significant interactive effect of $\mathrm{P}$ addition $\times$ year on $\mathrm{N}_{2} \mathrm{O}$ emission (Table 1).

\section{Discussion}

\subsection{Comparisons of $\mathrm{N}_{2} \mathrm{O}$ emission}

The rates of $\mathrm{N}_{2} \mathrm{O}$ emission observed from the controls of $A A$ and $E U$ plantations ( 1.9 to $2.3 \mathrm{~kg} \mathrm{~N}_{2} \mathrm{O}-\mathrm{N} \mathrm{ha}^{-1} \mathrm{yr}^{-1}$ ) are comparable with previous reports in (sub)tropical regions of southern China (2.0 to $4.8 \mathrm{~kg} \mathrm{~N}_{2} \mathrm{O}-\mathrm{N} \mathrm{ha}^{-1} \mathrm{yr}^{-1}$ ) (Zhang et al., 2008; Zhu et al., 2013a), and also within the range of published results $\left(1.2-2.6 \mathrm{~kg} \mathrm{~N}_{2} \mathrm{O}-\mathrm{Nha}^{-1} \mathrm{yr}^{-1}\right)$ from other tropical forests (Werner et al., 2007; Gharahi Ghehi et al., 2012). Higher rates of $\mathrm{N}_{2} \mathrm{O}$ emissions $\left(3.7-7.5 \mathrm{~kg} \mathrm{~N}_{2} \mathrm{O}\right.$ $\mathrm{Nha}^{-1} \mathrm{yr}^{-1}$ ) than our study were also reported from tropical forests (Keller and Reiners, 1994; Kiese and ButterbachBahl, 2002). However, our result is above the reported average $\mathrm{N}_{2} \mathrm{O}$ emissions of 0.1 to $0.7 \mathrm{~kg} \mathrm{~N}_{2} \mathrm{O}-\mathrm{N} \mathrm{ha}^{-1} \mathrm{yr}^{-1}$ for pine forests in southwestern China (Wang et al., 2010), probably due to the higher $\mathrm{pH}$ values of these pine forest soils.

The $A A$ plantation had significantly higher $\mathrm{N}_{2} \mathrm{O}$ emissions than those of the $E U$ stand, which was consistent with our expectation. Our result supports the notion that leguminous tree plantations in tropics and subtropics may potentially emit 
more $\mathrm{N}_{2} \mathrm{O}$ (Arai et al., 2008; Konda et al., 2008). The presence of leguminous trees resulted in higher soil $\mathrm{N}$ availability, including higher rates of net $\mathrm{N}$ mineralization and nitrification than in the $E U$ stand, which was considered to be the main reason for the higher rate of $\mathrm{N}_{2} \mathrm{O}$ emission from the $A A$ plantation, as also found by Dick et al. (2006). Leguminous trees can not only supply $\mathrm{N}$ via their unique ability of $\mathrm{N}$ fixing but also increase soil $\mathrm{C}$ content (Li et al., 2012). The higher SOC and fertility in the $A A$ plantation compared to $E U$ plantation may also partly explain the higher $\mathrm{N}_{2} \mathrm{O}$ emission from the $A A$ plantation. Additionally, soil $\mathrm{pH}$ of the $A A$ plantation was $0.5-0.7$ lower than that of the $E U$ site, which might directly or indirectly increase $\mathrm{N}_{2} \mathrm{O}$ emission from the $A A$ stand (Liu et al., 2010).

\subsection{Effects of $\mathrm{N}$ application on $\mathrm{N}_{2} \mathrm{O}$ emission}

Consistent with our hypothesis, the soil of $A A$ plantation responded to $\mathrm{N}$ addition greater than the $E U$ stand, with a large and immediate loss of $\mathrm{N}_{2} \mathrm{O}$ emission. The increase of soil $\mathrm{N}_{2} \mathrm{O}$ emissions following $\mathrm{NH}_{4}^{+}$or $\mathrm{NO}_{3}^{-}$addition was observed in many N-rich ecosystems (Butterbach-Bahl et al., 1998; Hall and Matson, 1999; Koehler et al., 2009). In the present study, the result from $A A$ plantation is consistent with the reported results that $\mathrm{N}$ additions could increase $\mathrm{N}_{2} \mathrm{O}$ emissions from $\mathrm{N}$-rich forest soils (Venterea et al., 2003; Zhang et al., 2008). Whereas the result from the $E U$ site is more comparable to the findings from N-poor forests (Matson et al., 1992; Zhang et al., 2008), where $\mathrm{N}$ addition did not enhance $\mathrm{N}_{2} \mathrm{O}$ emissions.

There are several factors causing the different responses of soil $\mathrm{N}_{2} \mathrm{O}$ emissions to $\mathrm{N}$ addition between the $A A$ and $E U$ plantations. The initial soil $\mathrm{N}$ status between both plantations contributed to the different responses of $\mathrm{N}_{2} \mathrm{O}$ emissions to $\mathrm{N}$ addition. The $A A$ plantation was abundant in symbiotic $\mathrm{N}$ fixers (Azotobacter), which act to incorporate large amounts of $\mathrm{N}$ into the soil (Hedin et al., 2009). Therefore, the $A A$ plantation presents an initial N-rich soil, while the $E U$ plantation dominated by Eucalyptus spp. did not. Moreover, the rates of net $\mathrm{N}$ mineralization and nitrification in the $A A$ plantation were significantly increased following $\mathrm{N}$ applications. This might be another potential cause of the different responses. For the $E U$ plantation, the fast growing trees of Eucalyptus spp. may have strong competition with microbes (e.g., nitrifying and denitrifying bacteria) for $\mathrm{N}$ uptake (Forrester et al., 2006), which was proved by the increase in $\mathrm{N}$ concentrations of leaf litter following $\mathrm{N}$ addition. The changes of soil MBC and MBN contents following $\mathrm{N}$ applications were not found in the $E U$ plantation, so the vegetation sink for $\mathrm{N}$ would be a buffer and provide the resistance in preventing $\mathrm{N}$ losses as $\mathrm{N}_{2} \mathrm{O}$ emission (Attiwill et al., 2001). There was also no evidence for the changes in soil MBC and MBN of the $A A$ plantation, which might be caused by adequate $\mathrm{N}$ availability for plants and microbes in this ecosystem.
A lower soil $\mathrm{C}: \mathrm{N}$ ratio of $A A$ plantation with $\mathrm{N}$ addition was likely the other cause of the different response. Multiple regression analysis indicated the variations of $\mathrm{C}: \mathrm{N}$ had a potential contribution to $\mathrm{N}_{2} \mathrm{O}$ fluxes. The decrease in soil $\mathrm{C}: \mathrm{N}$ ratio following $\mathrm{N}$ addition resulted in a "hotspot" for nitrification and/or denitrification of the $A A$ plantation (Barnard et al., 2005). Additionally, soil acidity has been reported to support high $\mathrm{N}_{2} \mathrm{O}$ emissions by denitrification (Liu et al., 2010). A lower soil $\mathrm{pH}$ after $\mathrm{N}$ application might contribute to the increase in $\mathrm{N}_{2} \mathrm{O}$ emission from the $A A$ plantation. Further works should be conducted to determine whether such a link exists.

\subsection{Effects of $\mathrm{P}$ application on $\mathrm{N}_{2} \mathrm{O}$ emissions}

$\mathrm{P}$ addition promoted uptake of $\mathrm{N}$ by plants (Hall and Matson, 1999), which could reduce $\mathrm{N}_{2} \mathrm{O}$ emission by decreasing $\mathrm{N}$ substrate. Higher plant $\mathrm{N}$ uptake could lead to decrease $\mathrm{N}$ availability for microbial nitrification and denitrification that would be lost as $\mathrm{N}_{2} \mathrm{O}$ from the soil of $E U$ plantation. Sundareshwar et al. (2003) also reported that $\mathrm{P}$ addition to sediment from a coastal salt marsh in South Carolina decreased $\mathrm{N}_{2} \mathrm{O}$ emissions by increasing $\mathrm{N}$ immobilization. On the contrary, in an incubation experiment (excluded plant), Mori et al. (2010) found that $\mathrm{P}$ addition increased $\mathrm{N}_{2} \mathrm{O}$ emissions from soil underneath an Acacia mangium plantation. They suggested that the possible mechanism might be $\mathrm{P}$ addition stimulated $\mathrm{N}$ cycling and relieved the $\mathrm{P}$ shortage for nitrifying and/or denitrifying bacteria; however, the competition for $\mathrm{N}$ by plants was ignored. Falkiner et al. (1993) reported that application of $\mathrm{P}$ increased soil net $\mathrm{N}$ mineralization of a Eucalyptus spp. forest in Australian, but almost the entire mineral $\mathrm{N}$ utilized by the vegetation. For our $E U$ plantation, the significant increases in $\mathrm{P}$ concentrations and decreases in $\mathrm{N}: \mathrm{P}$ ratios of leaf litter proved that $\mathrm{P}$ addition increased $\mathrm{P}$ uptake, leading to faster $\mathrm{N}$ uptake by plants as well. $\mathrm{P}$ addition did not change $\mathrm{N}_{2} \mathrm{O}$ emission from the $A A$ plantation soil. The reason for this is currently not clear. Further study is necessary to identify causal relationships between $\mathrm{N}_{2} \mathrm{O}$ emission, $\mathrm{N}$ availability of leguminous tree plantations and nutrient additions.

Additionally, Mori et al. (2010) reported that P addition decreasing $\mathrm{N}_{2} \mathrm{O}$ emission could be associated with increased other microbe immobilization of $\mathrm{N}$ after $\mathrm{P}$ addition, decreasing the $\mathrm{N}$ substrate for nitrifying and denitrifying bacteria. In the present study, net $\mathrm{N}$-mineralization and nitrification rates, as well as soil MBC and MBN contents, did not change following $\mathrm{P}$ applications. Therefore, it is unlikely that a microbial immobilization mechanism would explain the trend in our results.

\subsection{Interaction of $\mathrm{N}$ and $\mathrm{P}$ on $\mathrm{N}_{2} \mathrm{O}$ emission}

Application of $\mathrm{N}$ and $\mathrm{P}$ together tended to increase $\mathrm{N}_{2} \mathrm{O}$ emissions from the soil of $A A$ plantation in the first year. 
Table 3. $\mathrm{N}_{2} \mathrm{O}$ emission factor.

\begin{tabular}{|c|c|c|c|c|}
\hline Plantation type & Treatments & $\begin{array}{r}\mathrm{N}_{2} \mathrm{O} \text { emission } \\
\left(\mathrm{kg} \mathrm{Nha}^{-1} \mathrm{yr}^{-1}\right)\end{array}$ & $\begin{array}{r}\mathrm{N} \text { addition } \\
\left(\mathrm{kg} \mathrm{Nha}^{-1} \mathrm{yr}^{-1}\right)\end{array}$ & $\begin{array}{r}\mathrm{N}_{2} \mathrm{O} \text { emission } \\
\text { factor }(\%)\end{array}$ \\
\hline \multirow{5}{*}{$A A$} & $\mathrm{C}$ & $2.3(0.1) \mathrm{a}$ & 0 & \\
\hline & $\mathrm{MN}$ & $2.6(0.2) \mathrm{ab}$ & 50 & $0.72(0.17) \mathrm{ab}$ \\
\hline & $\mathrm{HN}$ & $3.1(0.1) \mathrm{b}$ & 100 & $0.81(0.09) b$ \\
\hline & MNP & $2.6(0.0) \mathrm{ab}$ & 50 & $0.64(0.11) \mathrm{ab}$ \\
\hline & HNP & $2.7(0.1) a b$ & 100 & $0.41(0.04) \mathrm{a}$ \\
\hline \multirow{5}{*}{$E U$} & $\mathrm{C}$ & $1.9(0.1)$ & 0 & \\
\hline & $\mathrm{MN}$ & $1.9(0.1)$ & 50 & $0.11(0.03)$ \\
\hline & $\mathrm{HN}$ & $2.0(0.2)$ & 100 & $0.15(0.04)$ \\
\hline & MNP & $2.1(0.1)$ & 50 & $0.34(0.07)$ \\
\hline & HNP & $2.1(0.0)$ & 100 & $0.23(0.04)$ \\
\hline
\end{tabular}

Gas samples were collected from August 2010 to July 2012. Values are presented as means with SE in parentheses $(n=3)$. Different letters in the same column indicate significantly different mean values among treatments of each stand (Tukey's HSD test, $p \leq 0.05$ ). $\mathrm{N}_{2} \mathrm{O}$ emission factor of a block was calculated as (annual $\mathrm{N}_{2} \mathrm{O}-\mathrm{N}$ emission of

$\mathrm{N}$-treatment plot - annual $\mathrm{N}_{2} \mathrm{O}-\mathrm{N}$ emission of the control plot)/(total $\mathrm{N}$ applied in each year). AA, Acacia auriculiformis plantation; EU, Eucalyptus urophylla plantation.

The result was in line with the report that addition of $\mathrm{NO}_{3}^{-}$ with $\mathrm{P}$ together stimulated soil $\mathrm{N}_{2} \mathrm{O}$ emissions from Acacia mangium plantation soil (Mori et al., 2013). The increase in $\mathrm{N}_{2} \mathrm{O}$ emission was attributed to the fact that the added $\mathrm{N}$ increased substrates (Xu et al., 2012), and the added P stimulated nitrification and denitrification by relieving $\mathrm{P}$ shortage for nitrifying and denitrifying bacteria (Minami and Fukushi, 1983). However, $\mathrm{NP}$ addition decreased $\mathrm{N}_{2} \mathrm{O}$ emission compared to $\mathrm{N}$ addition in the $A A$ plantation. The main cause of this might be that most of added $\mathrm{N}$ was absorbed and utilized by the vegetation after relieving the $\mathrm{P}$ shortage by applied $\mathrm{P}$ together. Further study is necessary to identify nutrient competition between soil microorganisms and plant growth after nutrient applications in tropical leguminous tree plantations.

\subsection{Effects of soil temperature and WFPS on $\mathrm{N}_{2} \mathrm{O}$ emission}

In the study, $\mathrm{N}_{2} \mathrm{O}$ fluxes showed positive linear relationships with soil temperatures and WFPS, which were consistent with tropical and subtropical forests (Butterbach-Bahl et al., 2004; Zhang et al., 2008; Zhu et al., 2013a). There is a covariation between soil temperature and WFPS in the monsoon climate zone of southern China. The interaction of soil temperature and WFPS may constrain the processes of nitrification and denitrification, which mainly control the production of $\mathrm{N}_{2} \mathrm{O}$ emission (Barnard et al., 2005). Multiple linear regression analysis indicated that the variability of $\mathrm{N}_{2} \mathrm{O}$ emissions is significantly related to the changes of soil temperature $\left(p=6.1 \times 10^{-8}\right.$ and $\left.7.6 \times 10^{-8}\right)$ and WFPS $(p=$ $7.0 \times 10^{-5}$ and $9.2 \times 10^{-5}$ for the $A A$ and $E U$ stand, respectively) of each stand (Table 2). The results showed that when comparing to WFPS, soil temperature is a more important controlling factor for $\mathrm{N}_{2} \mathrm{O}$ emissions in the studied plantations $\left(p=1.4 \times 10^{-12}\right.$ and $2.6 \times 10^{-8}$ for soil tem- perature and WFPS, respectively). $\mathrm{N}_{2} \mathrm{O}$ emission increases with increasing soil temperature due to the fact that rates of enzymatic processes generally increase with temperature as long as other factors (e.g., substrate or WFPS) are not limiting (Smith et al., 1998; Pilegaard et al., 2006). Increasing soil moisture would increase soil microbial activities and therefore $\mathrm{N}_{2} \mathrm{O}$ production (Rowlings et al., 2012). On the other hand, increased soil moisture under warm conditions could exponentially increase denitrification (Arah and Smith, 1989). There were no differences between treatments and the controls in each plantation, which indicated that nutrient additions did not change the relationships of $\mathrm{N}_{2} \mathrm{O}$ fluxes with soil temperature or WFPS.

\section{6 $\mathrm{N}_{2} \mathrm{O}$ emission factors}

According to $\mathrm{N}$-addition and NP-addition plots, $\mathrm{N}_{2} \mathrm{O}$ emission factors based on percentage of applied $\mathrm{N}$ ranged between $0.7 \%$ to $0.8 \%$ and $0.1 \%$ to $0.3 \%$ for treatment level in $A A$ and $E U$ plantation, respectively (Table 3). The $\mathrm{N}_{2} \mathrm{O}$ emission factor of $A A$ plantation was similar to the average of $0.9 \%$ for forest ecosystems (Liu and Greaver, 2009), and the IPCC default factor (1\%) (IPCC, 2007). It is among the lowest range of data from other tropical forests (1-9\%) (Hall and Matson, 1999; Steudler et al., 2002). On the contrary, Zhu et al. (2013b) reported that emission factors amounted to $8-10 \%$ of $\mathrm{N}$ deposition in subtropical forests of southern China. In our study, the lower $\mathrm{N}_{2} \mathrm{O}$ emission factor might be due to the short term of the experiment ( $2 \mathrm{yr})$, and the plantations planted on eroded soils are relatively poor in nutrients compared with natural forest soils. Compared to $\mathrm{HN}$ treatment, HNP addition significantly decreased the $\mathrm{N}_{2} \mathrm{O}$ emission factor by $50 \%$ in the $A A$ plantation (Table $3 ; p=0.04$ ). This result suggests that the combined application of $\mathrm{N}$ and $\mathrm{P}$ together may probably mitigate $\mathrm{N}_{2} \mathrm{O}$ emission in comparison 
with $\mathrm{N}$ fertilization alone in tropical leguminous tree plantations.

\section{Conclusions}

The responses of soil $\mathrm{N}_{2} \mathrm{O}$ emissions to nutrient additions were studied in two tropical plantations with $\mathrm{N}$-fixing and non-N-fixing tree species. We found that leguminous tree plantations in the study region may potentially emit more $\mathrm{N}_{2} \mathrm{O}$ after $\mathrm{N}$ addition, due to its high initial soil $\mathrm{N}$ availability. Application of $\mathrm{N}$ and $\mathrm{P}$ together decreased the rate of $\mathrm{N}_{2} \mathrm{O}$ emission compared to $\mathrm{N}$ treatment alone in $\mathrm{N}$-fixing tree plantations, while application of $\mathrm{P}$ alone significantly reduced $\mathrm{N}_{2} \mathrm{O}$ emission from non-N-fixing tree plantations. The main cause of these might be that most of $\mathrm{N}$ was absorbed and utilized by the vegetation with $\mathrm{P}$ application in these tropical plantations. As far as we know, this study is among the first to investigate the effect of nutrient additions on soil $\mathrm{N}_{2} \mathrm{O}$ emissions from tropical plantations with $\mathrm{N}$ fixing vs. non-N-fixing tree species. The results indicate that the projected increase of atmospheric $\mathrm{N}$ deposition would potentially increase soil $\mathrm{N}_{2} \mathrm{O}$ emissions from leguminous tree plantations. Our findings also suggest that moderate fertilization of $\mathrm{P}$ might eventually reduce $\mathrm{N}$-deposition-induced $\mathrm{N}_{2} \mathrm{O}$ emissions from leguminous tree plantations in the tropical and subtropical regions.

\section{The Supplement related to this article is available online at doi:10.5194/bg-11-4941-2014-supplement.}

Acknowledgements. This research was financially supported by the National Key Basic Research 973 Program (2010CB833502) and the National Natural Science Foundation of China (nos. 31000236 and 31370011). The authors wish to acknowledge Shengxing Fu for gas sampling, and Frank S. Gilliam and Dejun Li for their constructive comments that improved the quality of the manuscript.

Edited by: A. Neftel

\section{References}

Anderson, J. M. and Ingram, J. S. I.: Tropical Soil Biology and Fertility, in: a Handbook of Methods, Wallingford, UK, CAB International, 1989.

Arah, J. R. M. and Smith, K. A. Steady-state denitrification in aggregated soils: a mathematical model, J. Soil Sci., 40, 139-149, 1989.

Arai, S., Ishizuka, S., Ohta, S., Ansori, S., Tokuchi, N., Tanaka, $\mathrm{N}$., and Hardjono, A.: Potential $\mathrm{N}_{2} \mathrm{O}$ emissions from leguminous tree plantation soils in the humid tropics, Global Biogeochem. Cy., 22, GB2028, doi:10.1029/2007GB002965, 2008.
Attiwill, P. M. and May, B. M.: Does nitrogen limit the growth of native eucalypt forests: some observations for mountain ash (Eucalyptus regnans), Mar. Freshwater Res., 52, 111-117, doi:10.1071/MF00046, 2001.

Barnard, R., Leadley, P. W., and Hungate, B. A.: Global change, nitrification, and denitrification: a review, Global Biogeochem. Cy., 19, GB1007, doi:10.1029/2004gb002282, 2005.

Bremner, J. M. and Mulvaney, C. S.: Total nitrogen, in: Methods of Soil Analysis, edited by: Page, A. L., Miller, R. H., and Keeny, D. R., American Society of Agronomy and Soil Science Society of America, Madison, 1119-1123, 1982.

Butterbach-Bahl, K., Gasche, R., Huber, C., Kreutzer, K., Papen, $\mathrm{H}$.: Impact of $\mathrm{N}$-input by wet deposition on $\mathrm{N}$-trace gas fluxes and $\mathrm{CH}_{4}$-oxidation in spruce forest ecosystems of the temperate zone in Europe, Atmos. Environ., 32, 559-564, 1998.

Butterbach-Bahl, K., Kock, M., Willibald, G., Hewett, B., Buhagiar, S., Papen, H., and Kiese, R.: Temporal variations of fluxes of $\mathrm{NO}, \mathrm{NO}_{2}, \mathrm{~N}_{2} \mathrm{O}, \mathrm{CO}_{2}$, and $\mathrm{CH}_{4}$ in a tropical rain forest ecosystem, Global Biogeochem. Cy., 18, GB3012, doi:10.1029/2004gb002243, 2004.

Cabrera, M. L. and Beare, M. H.: Alkaline persulfate oxidation for determining total nitrogen in microbial biomass extracts, Soil Sci. Soc. Am. J., 57, 1007-1012, 1993.

Chen, D. M., Zhang, C. L., Wu, J. P., Zhou, L. X., Lin, Y. B., and Fu, S. L.: Subtropical plantations are large carbon sinks: evidence from two monoculture plantations in South China, Agr. Forest Meteorol., 151, 1214-1225, 2011.

Dick, J., Skiba, U., Munro, R., and Deans, D.: Effect of N-fixing and non $\mathrm{N}$-fixing trees and crops on $\mathrm{NO}$ and $\mathrm{N}_{2} \mathrm{O}$ emissions from Senegalese soils, J. Biogeogr., 33, 416-423, 2006.

Dong, M., Wang, Y. F., Kong, F. Z., Jiang, G. M., and Zhang, Z. B.: Standard methods for observation and analysis in Chinese Ecosystem Research Network: survey, observation and analysis of terrestrial biocommunities, Standards Press of China, Beijing, 1-80, 1996 (in Chinese).

Falkiner, R. A., Khanna, P. K., and Raison, R. J.: Effect of Superphosphate Addition on N-Mineralization in Some Australian Forest Soils, Aust. J. Soil Res., 31, 285-296, 1993.

FAOUN, Food and Agriculture Organization of the United Nations, Global Forest Resources Assessment 2010: Main Report, FAO Forestry Paper, vol. 163, Food and Agric. Org. of the UN, Rome, 2010.

Forrester, D. I., Bauhus, J., Cowie, A. L., and Vanclay, J. K.: Mixedspecies plantations of Eucalyptus with nitrogen-fixing trees: a review, Forest Ecol. Manag., 233, 211-230, 2006.

Galloway, J. N., Townsend, A. R., Erisman, J. W., Bekunda, M., Cai, Z., Freney, J. R., Martinelli, L. A., Seitzinger, S. P., and Sutton, M. A.: Transformation of the nitrogen cycle: recent trends, questions, and potential solutions, Science, 320, 889-892, 2008.

Gharahi Ghehi, N., Werner, C., Cizungu Ntaboba, L., Mbonigaba Muhinda, J. J., Van Ranst, E., Butterbach-Bahl, K., Kiese, R., and Boeckx, P.: Spatial variations of nitrogen trace gas emissions from tropical mountain forests in Nyungwe, Rwanda, Biogeosciences, 9, 1451-1463, doi:10.5194/bg-9-1451-2012, 2012.

Hall, S. J. and Matson, P. A.: Nitrogen oxide emissions after nitrogen additions in tropical forests, Nature, 400, 152-155, 1999. 
Hedin, L. O., Brookshire, E. N. J., Menge, D. N. L., and Barron, A.: The nitrogen paradox in tropical forest ecosystems, Annu. Rev. Ecol. Evol. S., 40, 613-635, 2009.

Holland, E. A., Robertson, G. P., Greenberg, J., Groffman, P. M., Boone, R. D., and Gosz, J. R.: Soil $\mathrm{CO}_{2}, \mathrm{~N}_{2} \mathrm{O}$, and $\mathrm{CH}_{4}$ exchange, in: Standard Soil Methods for Long-Term Ecological Research, edited by: Robertson, G. P., Oxford University Press, New York, NY, USA, 185-201, 1999.

IPCC: Changes in Atmospheric Constituents and in Radiative Forcing. Climate Change 2007: The Physical Science Basis, Contribution of Working Group I to the Fourth Assessment Report of the Intergovernmental Panel on Climate Change, edited by: Solomon, S., Qin, D., Manning, M., Chen, Z., Marquis, M., Averyt, K. B., Tignor, M., and Miller, H. L., Cambridge University Press, Cambridge, UK and New York, NY, USA, 210-215, 2007.

Keller, M. and Reiners, W. A.: Soil atmosphere exchange of nitrousoxide, nitric-oxide, and methane under secondary succession of pasture to forest in the Atlantic lowlands of Costa-Rica, Global Biogeochem. Cy., 8, 399-409, 1994.

Kiese, R. and Butterbach-Bahl, $\mathrm{K} .: \mathrm{N}_{2} \mathrm{O}$ and $\mathrm{CO}_{2}$ emissions from three different tropical forest sites in the wet tropics of Queensland, Australia, Soil Biol. Biochem., 34, 975-987, 2002.

Koehler, B., Corre, M. D., Veldkamp, E., Wullaert, H., and Wright, S. J.: Immediate and long-term nitrogen oxide emissions from tropical forest soils exposed to elevated nitrogen input, Glob. Change Biol., 15, 2049-2066, 2009.

Konda, R., Ohta, S., Ishizuka, S., Arai, S., Ansori, S., Tanaka, N., and Hardjono, A.: Spatial structures of $\mathrm{N}_{2} \mathrm{O}, \mathrm{CO}_{2}$, and $\mathrm{CH}_{4}$ fluxes from Acacia mangium plantation soils during a relatively dry season in Indonesia, Soil Biol. Biochem., 40, 3021-3030, 2008.

Li, D. J., Niu, S. L., and Luo, Y. Q.: Global patterns of the dynamics of soil carbon and nitrogen stocks following afforestation: a meta-analysis, New Phytol., 195, 172-181, 2012.

Liu, B. B., Morkved, P. T., Frostegard, A., and Bakken, L. R.: Denitrification gene pools, transcription and kinetics of $\mathrm{NO}, \mathrm{N}_{2} \mathrm{O}$ and $\mathrm{N}_{2}$ production as affected by soil $\mathrm{pH}$, FEMS Microbiol. Ecol., 72, 407-417, 2010.

Liu, G. S., Jiang, N. H., Zhang, L. D., and Liu, Z. L.: Soil Physical and Chemical Analysis and Description of Soil Profiles, Standards Press of China, Beijing, 1996 (in Chinese).

Liu, L. L. and Greaver, T. L.: A review of nitrogen enrichment effects on three biogenic GHGs: the $\mathrm{CO}_{2}$ sink may be largely offset by stimulated $\mathrm{N}_{2} \mathrm{O}$ and $\mathrm{CH}_{4}$ emission, Ecol. Lett., 12, 1103$1117,2009$.

Liu, X. J., Zhang, Y., Han, W. X., Tang, A. H., Shen, J. L., Cui, Z. L., Vitousek, P., Erisman, J. W., Goulding, K., Christie, P., Fangmeier, A., and Zhang, F. S.: Enhanced nitrogen deposition over China, Nature, 494, 459-462, 2013.

Martinson, G. O., Corre, M. D., and Veldkamp, E.: Responses of nitrous oxide fluxes and soil nitrogen cycling to nutrient additions in montane forests along an elevation gradient in southern Ecuador, Biogeochemistry, 112, 625-636, 2013.

Matson, P. A., Gower, S. T., Volkmann, C., Billow, C., and Grier, C. C.: Soil-nitrogen cycling and nitrous-oxide flux in a rocky-mountain Douglas-Fir forest - effects of fertilization, irrigation and carbon addition, Biogeochemistry, 18, 101-117, 1992.
Minami, K. and Fukushi, S.: Effects of phosphate and calciumcarbonate application on emission of $\mathrm{N}_{2} \mathrm{O}$ from soils under aerobic conditions, Soil Sci. Plant Nutr., 29, 517-524, 1983.

Mori, T., Ohta, S., Ishizuka, S., Konda, R., Wicaksono, A., Heriyanto, J., and Hardjono, A.: Effects of phosphorus addition on $\mathrm{N}_{2} \mathrm{O}$ and $\mathrm{NO}$ emissions from soils of an Acacia mangium plantation, Soil Sci. Plant Nutr., 56, 782-788, 2010.

Mori, T., Ohta, S., Ishizuka, S., Konda, R., Wicaksono, A., Heriyanto, J., and Hardjono, A.: Effects of phosphorus addition with and without ammonium, nitrate, or glucose on $\mathrm{N}_{2} \mathrm{O}$ and $\mathrm{NO}$ emissions from soil sampled under Acacia mangium plantation and incubated at $100 \%$ of the water-filled pore space, Biol. Fert. Soils, 49, 13-21, 2013.

Peng, S. L., Hou, Y. P., and Chen, B. M.: Vegetation restoration and its effects on carbon balance in Guangdong Province, China, Restor. Ecol., 17, 487-494, 2009.

Pilegaard, K., Skiba, U., Ambus, P., Beier, C., Brüggemann, N., Butterbach-Bahl, K., Dick, J., Dorsey, J., Duyzer, J., Gallagher, M., Gasche, R., Horvath, L., Kitzler, B., Leip, A., Pihlatie, M. K., Rosenkranz, P., Seufert, G., Vesala, T., Westrate, H., and Zechmeister-Boltenstern, S.: Factors controlling regional differences in forest soil emission of nitrogen oxides ( $\mathrm{NO}$ and $\mathrm{N}_{2} \mathrm{O}$ ), Biogeosciences, 3, 651-661, doi:10.5194/bg-3-651-2006, 2006.

Ravishankara, A. R., Daniel, J. S., and Portmann, R. W.: Nitrous oxide $\left(\mathrm{N}_{2} \mathrm{O}\right)$ : the dominant ozone-depleting substance emitted in the 21 st century, Science, 326, 123-125, 2009.

Reay, D. S., Dentener, F., Smith, P., Grace, J., and Feely, R. A.: Global nitrogen deposition and carbon sinks, Nat. Geosci., 1, 430-437, 2008.

Rowlings, D. W., Grace, P. R., Kiese, R., and Weier, K. L.: Environmental factors controlling temporal and spatial variability in the soil-atmosphere exchange of $\mathrm{CO}_{2}, \mathrm{CH}_{4}$ and $\mathrm{N}_{2} \mathrm{O}$ from an Australian subtropical rainforest, Glob. Change Biol., 18, 726-738, 2012.

Smith, K. A., Thomson, P. E., Clayton, H., McTaggart, I. P., and Conen, F.: Effects of temperature, water content and nitrogen fertilisation on emissions of nitrous oxide by soils, Atmos. Environ., 32, 3301-3309, 1998.

Steudler, P. A., Garcia-Montiel, D. C., Piccolo, M. C., Neill, C., Melillo, J. M., Feigl, B. J., and Cerri, C. C.: Trace gas responses of tropical forest and pasture soils to $\mathrm{N}$ and $\mathrm{P}$ fertilization, Global Biogeochem. Cy., 16, 1023, doi:10.1029/2001GB001394, 2002.

Stocker, B. D., Roth, R., Joos, F., Spahni, R., Steinacher, M., Zaehle, S., Bouwman, L., Xu, R., and Prentice, I. C.: Multiple greenhouse-gas feedbacks from the land biosphere under future climate change scenarios, Nat. Clim. Change, 3, 666-672, 2013.

Sundareshwar, P. V., Morris, J. T., Koepfler, E. K., and Fornwalt, B.: Phosphorus limitation of coastal ecosystem processes, Science, 299, 563-565, 2003.

Tu, C., Louws, F. J., Creamer, N. G., Mueller, J. P., Brownie, C., Fager, K., Bell, M., and Hu, S. J.: Responses of soil microbial biomass and $\mathrm{N}$ availability to transition strategies from conventional to organic farming systems, Agr. Ecosyst. Environ., 113 206-215, 2006.

Vance, E. D., Brookes, P. C., and Jenkinson, D. S.: An Extraction Method for Measuring Soil Microbial Biomass-C, Soil Biol. Biochem., 19, 703-707, 1987.

Venterea, R. T., Groffman, P. M., Verchot, L. V., Magill, A. H., Aber, J. D., and Steudler, P. A.: Nitrogen oxide gas emissions 
from temperate forest soils receiving long-term nitrogen inputs, Glob. Change Biol., 9, 346-357, 2003.

Vitousek, P. M., Aber, J. D., Howarth, R. W., Likens, G. E., Matson, P. A., Schindler, D. W., Schlesinger, W. H., and Tilman, D.: Human alteration of the global nitrogen cycle: sources and consequences, Ecol. Appl., 7, 737-750, 1997.

Vitousek, P. M., Porder, S., Houlton, B. Z., and Chadwick, O. A.: Terrestrial phosphorus limitation: mechanisms, implications, and nitrogen-phosphorus interactions, Ecol. Appl., 20, 5-15, 2010.

Wang, H., Liu, S. R., Mo, J. M., and Zhang, T.: Soil-atmosphere exchange of greenhouse gases in subtropical plantations of indigenous tree species, Plant Soil, 335, 213-227, 2010.

Werner, C., Kiese, R., and Butterbach-Bahl, K.: Soil-atmosphere exchange of $\mathrm{N}_{2} \mathrm{O}, \mathrm{CH}_{4}$, and $\mathrm{CO}_{2}$ and controlling environmental factors for tropical rain forest sites in western Kenya, J. Geophys. Res., 112, D03308, doi:10.1029/2006JD007388, 2007.

$\mathrm{Xu}$, R., Prentice, I. C., Spahni, R., and Niu, H. S.: Modelling terrestrial nitrous oxide emissions and implications for climate feedback, New Phytol., 196, 472-488, 2012.

Zhang, W., Mo, J. M., Yu, G. R., Fang, Y. T., Li, D. J., Lu, X. K., and Wang, H.: Emissions of nitrous oxide from three tropical forests in Southern China in response to simulated nitrogen deposition, Plant Soil, 306, 221-236, 2008.
Zhang, W., Zhu, X. M., Liu, L., Fu, S. L., Chen, H., Huang, J., Lu, X. K., Liu, Z. F., and Mo, J. M.: Large difference of inhibitive effect of nitrogen deposition on soil methane oxidation between plantations with $\mathrm{N}$-fixing tree species and non-N-fixing tree species, J. Geophys. Res., 117, G00N16, doi:10.1029/2012jg002094, 2012.

Zhu, J., Mulder, J., Wu, L. P., Meng, X. X., Wang, Y. H., and Dörsch, P.: Spatial and temporal variability of $\mathrm{N}_{2} \mathrm{O}$ emissions in a subtropical forest catchment in China, Biogeosciences, 10, 1309-1321, doi:10.5194/bg-10-1309-2013, 2013a.

Zhu, J., Mulder, J., Solheimslid, S. O., and Dörsch, P.: Functional traits of denitrification in a subtropical forest catchment in China with high atmogenic $\mathrm{N}$ deposition, Soil Biol. Biochem., 57, 577586, $2013 b$.

Zhu, W. X. and Carreiro, M. M.: Chemoautotrophic nitrification in acidic forest soils along an urban-to-rural transect, Soil Biol. Biochem., 31, 1091-1100, 1999. 